setting forth, as they do, characterizations of the several genera and species to which the author has given his attention.

R. W. ShUFELDT.

Takoma, D. C., Aug. 15.

\section{The Color of the Blood in Man.}

HAVING recently examined a large number of specimens of human blood from persons of different ages ranging from four to seventy-six years, some being those in robust health, others being tuberculous, I was struck with the great difference in the shade of color presented, some being of a very rich tint, others very pale. The richest color was in the blood of a girl twentysix years of age, a graduate of Vassar College, who had the highest anthropometric measurement for respiratory capacity in a class of about 500 girls. Her health was excellent, and she consumed rather more flesh-food than is usual. The next highest tint was found in the blood of a woman about seventy years old, with a somewhat unusual chest measurement, having also excellent respiratory capacity and being in fine health. This woman, on the contrary, does rot eat flesh at all. I expected in ber case to find a more than ordinary number of white blood corpuscles; but there were far less than usual, it being difficult to find them, they were so few. The palest blood was from a chlorotic Irish servant-girl of twenty-five years, and in a tuberculous boy of four. There was not much perceptible difference in their cases. The girl had naturally good respiratory power, but she had lessened it by tight clothing and an almost constant in-door life for a long time. After spending a month at the seaside, I examined her blood again, and found the tint somewhat deeper than before. As we know, the color of the blood is caused by the hæmoglobin in the red blood corpuscles, and if this is greater when the respiratory capacity is greatest, may not the color of the blood be heightened by enlarging the chest and increasing the lung-power? From some observations I have made I believe it can.

M. L. HolbrooK.

New York, Aug. 16.

\section{Snake Eats Snake.}

WHILE walking over a dry mesa, yesterday, I noticed a small snake slowly crawling to the shelter of a mesquit bush. On capturing it, I found it to be of a very dark olive-green color, in large, square pattern, the lines between the plaids being of lighter green; underneath, white, with very dark-green blotches. Its head was very dark green, and rather small; it had small fangs. The length of the snake was nineteen inches. Noticing that the body seemed much distended, I opened it, and found, nicely packed away inside, the body of an ordinary, brown, striped " grass snake," as we call them here, twenty-two inches long. This green snake may be a new species of snake-eating serpent. The grass snake is very swift, and I am puzzled to know how the green snake caught it; it was swallowed head-first.

Oro Blanco, Arizona, Aug. 8.

C. W. Kempton

\section{Cleistogamy in the Pansy.}

MR. DARWIN, in "Forms of Flowers," notes that, though cleistogamy is the rule in the genus Viola, the pansy, Viola tricolor, has not been known to exhibit it, though it does sometimes produce very small and closed self-fertilizing flowers, which would critically be termed cleistogamic if some portions of the floral organs were to abort. In our country this condition may more readily occur than in the Old World. In many localities the pansy has become partially wild and cleistogamy may be looked for. Mr. Chalkley Palmer has sent me some specimens in fruit, found wild in some place in New Jersey, which are certainly in one or the other condition noted by Mr. Darwin. They appear to be truly cleistogamic, but were too far advanced to determine with accuracy. Thomas Meehan.

\section{BOOK-REVIEWS}

Annual Report of the Geological Survey of Arkansas for 1890. Vol. III. Whetstones and the Novaculites of Arkansxs. By L. S. Griswold. Little Rock, Arkansas.

THE history of the rise and progress of geology in the United States remains to be written. It dates back to early in the century; for in 1807 McClure published a paper containing geological observations. Mitchell, Eaton, Dewey, Silliman, and hosts of others followed one another in rapid succession. Nor were the observations of private individuals all that appeared in the early decades, for in 1823 Olmsted published a report on the geology of North Carolina, as one result of a regularly organized State survey, while Hitchcock in 1831 reported upon the geology of Massachusetts. Between that date and 1840 State surveys had been organized and reports had been published in Maine, Connecticut, New York, New Jersey, Pennsylvania, Delaware, Maryland, Virginia, Georgia, Tennessee, Kentucky, Ohio, Indiana. and Michigan. The general government, too, had sent expeditions to the north-west, Schoolcraft reporting upon the Michigan region as early as 1820 . It is true that many of the State surveys ceased after the issuance of a few documents, but their existence even for a brief period was evidence of the belief in their value. Some of the States organized second surveys at a later date and published numerous rolumes, among which New Jersev, Pennsylvania, Ohio, and Kentucky are especially to be noted. The survey of New York has been continued from 1837 until the present time.

In those olden times the State survey reports were general; observations were made over an extended area; profuse details were given of township or county geology; but no one subject was treated in an exhaustive manner. The result was that, when ten or a dozen or more volumes had been published, it still remained to collate and epitomize the information. For the States of New York, Pennsylvania, ${ }^{1}$ Kentucky, Ohio, Illinois and others this has never been done, and the numerous volumes of these surveys are masses of details with full and comprehensive accounts of scarcely a single subject. Dr. Branner, as the State Geologist of Arkansas, has seen fit to change this ancient order of things, and as a result in his annual reports we have volumes describing the Mesozoic geology, the gold and silver fields, and the coal of the State, as well as exhaustive volumes on Manganese and the Noraculites. The first geological survey of Arkansas published two reports, in 1859 and 1860 . The beginning of the war put a stop to the work, howerer, and it was not until 1888 that any further work in the State was published. The report for that year, and those for 1889 and 1890 , of which the volume under review is the third, contain much information valuable alike to the State and to the world at large.

Whetting, or sharpening, is one of the ancient arts. That it was practised by early civilized man is evidenced by the existence in the Sanscrit of the word $c a$, meaning to sharpen or whet. From this comes the Latin cos, a whetstone, hone or flint-stone, and hence cotaria, a whetstone quarry. Coticula, meaning a small touch-stone, is also a derivative, and from this comes the French coticule, meaning a whetstone of a fine quality. Novaculite comes from novacula, a sharp knife or razor, and this in turn is derived from the Latin novare, to renew or to make fresh.

Many writers from Pliny down discuss whetstones or hones for sharpening tools. Linnæus used the word novacula in his time, and it was seemingly anglicized by Richard Kirwan into novaculite in 1784. Mr. Griswold believes, although all mineralogists do not agree with him, ${ }^{2}$ that it is practicable " to revive the word as a scientific term, in its original sense, to denote a fine-grained, gritty, homogeneous, and highly siliceous rock, translucent on thin edges, and having a conchoidal or sub-conchoidal fracture. If this definition is strictly adhered to, no confusion will arise from the use of the word in commerce" (p. 18).

The knowledge of whetstones in America dates from 1818, when they were mentioned by Bringier as occurring in Arkansas.

1 Professor J. L. Lesley is now engaged on this work, and Vol. I. of his flnal report has appeared.

2 For example, G. P. Merrill in Annual Report U. S. Nat. Mus. for 1890, 1892. p. 525 . 


\section{Science}

\section{Cleistogamy in the Pansy}

Thomas Meehan

Science ns-20 (498), 107

DOI: 10.1126/science.ns-20.498.107-b

ARTICLE TOOLS

PERMISSIONS http://science.sciencemag.org/content/ns-20/498/107.3.citation

http://www.sciencemag.org/help/reprints-and-permissions 